\title{
Tempeh flour as a substitute for soybean flour in coconut cookies
}

\author{
Rodrigo Santos LEITE ${ }^{1 \rtimes}$, Mercedes Concórdia CARRÃO-PANIZZI², Jessika Menck CURTI ${ }^{3}$, Isabela Pereira DIAS ${ }^{3}$, \\ Neusa Fátima SEIBEL ${ }^{3}$
}

\begin{abstract}
The objective of this study was to prepare roasted and lyophilized tempeh flour with soybean cultivar BRS 267 to apply them in the formulation of coconut biscuits. The cookies produced with whole soy flour and mixed flour of soybean and tempeh were evaluated for proximate composition, fatty acid profile, and isoflavone aglycones in order to verify the effects of inoculation with the fungus Rhizopus oligosporus and those of the drying processes of roasting and lyophilization on the chemical characteristics of the final product. Sensory acceptance and purchase intention of the formulated products were also evaluated. The results indicate the maintenance of linolenic acid, which is important in the prevention of coronary diseases, and an increase in the aglycones levels when the tempeh flour was used. Lipids and proteins showed differences, and the sensory analyses demonstrated similarity between the cookies with satisfactory scores for aroma, flavor, texture, and overall acceptability for both samples. when compared to the control. Purchase intent was also positive for the lyophilized and toasted tempeh flours, thus enabling the use of the roasting process as a simple drying method, for processing tempeh and obtaining a flour rich in proteins and aglycones that can be used as a partial substitute for soy flour in cookies and other bakery products.
\end{abstract}

Keywords: Rhizopus oligosporus; isoflavones; sensory analyses; fatty acids.

\section{Introduction}

Soybean (Glycine max L. Merrill) is an important oilseed which stands out for providing different products for human and animal nutrition with high economic value in the domestic and international market. In the 2012/2013 harvest, soybean world production was 285.89 million tons; the United States was the largest producer with a production of 93.08 million tons and a cultivated area of 31.13 million hectares, followed by Brazil, with an output of 66 million tons and an area of 28.25 million hectare (COMPANHIA..., 2013).

Interest for the processing and marketing soybean and its by-products for human consumption arouse from its protein content and the presence of isoflavones compounds in their chemical composition. Isoflavones are present in soy as glucosides, which are biologically inactive, or as aglycones, which are biologically active. After ingestion, the isoflavone glycosides (daidzin and genistin), are converted by the action of hydrochloric acid ( $\mathrm{HCl} \beta$-Glycosidases) present in the stomach and the bacteria present in the intestine into aglycones, which are their most active forms (TERESA et al., 2006). Isoflavones are involved in physiological processes that help reduce the risk of chronic degenerative and non-transmissible diseases, menopausal symptoms, osteoporosis, some cancers, and cardiovascular diseases, and these effects are associated with the consumption of soy (MCCUE; SHETTY, 2004).

Several authors have studied the benefits of solid state fermentation as an alternative for soybean processing for human consumption, especially those related with changes in isoflavone profile (FERREIRA et al., 2011; MO et al., 2013). Soybean flour fermentation, when performed under ideal conditions, can result in a significant increase in the content of aglycone (active forms) in the final product, with values up to $75.51 \%$ of total isoflavones (SILVA; CELEGHINI; CHANG, 2011).

Therefore, the use of tempeh flour, traditional product from Indonesia obtained from the fermentation of whole soybean cotyledons, in the presence of the fungus Rhizopus microsporus variety oligosporus (NOWAK; SZEBIOTKO, 1992) arises as an attractive alternative for products that contain soy flour among its ingredients. Tempeh flour is obtained by drying and grinding of fresh tempeh under controlled conditions of time and temperature. This process can be accomplished by traditional drying (SILVA et al., 2012) or lyophilization, an alternative process known by the preservation of chemical and sensory characteristics (FRANKS, 1998; TATTINI; PARRA; PITOMBO, 2006).

Before the application of mixed flours in bakery and confectionery, some aspects must be considered, such as rheological properties, physical, sensory or nutritional characteristics of raw materials used in the formulation, the costs of the mixture, and acceptability of the final product (GUILHERME; JOKL, 2005). Determining consumer acceptance is a crucial factor in the development of a product and involves a series of procedures (DANTAS et al, 2010). Therefore, affective methods can be applied to measure the subjective attitudes of acceptance or preference for a product (FERREIRA, 2000).

\section{Received 10/28/2013}

Accepted 10/29/2013 (006210)

${ }^{1}$ Embrapa Soja, Universidade Tecnológica Federal do Paraná - UTFPR, Carlos Strass Road, CP 231, CEP 86001-970, Londrina, PR, Brazil, e-mail: rodrigo.leite@embrapa.br

2 Embrapa Trigo, Rod. BR-285, Km 294, CP 451, CEP 99001-970, Passo Fundo, RS, Brasil

${ }^{3}$ Universidade Tecnológica Federal do Paraná - UTFPR, Av. dos Pioneiros, 3131 CEP 86036-370, Londrina, PR, Brasil

${ }^{*}$ Corresponding author 
Acceptance and purchase intent tests are useful when the objective is to evaluate whether consumers like or dislike the product. The scale rating of such tests can be balanced or unbalanced; balanced scale rating have an equal number of positive and negative categories, and the terms are equally separated (MINIM, 2006). The hybrid hedonic scale is one of the most widely used scales for affective tests; it has proved better than the traditional hedonic scale and the self-adjusting scales due to its discriminating power and reliability and validity of its results (VILLANUEVA; PETENATE; SILVA, 2005).

The objective of this paper was to elaborate roasted and lyophilized tempeh flours and use them to make coconut cookies in order to determine the chemical composition and sensory acceptability of the final product.

\section{Materials and methods}

Soybean grains from cultivar BRS 267, developed by Embrapa Soybean for human consumption (CARRÃOPANIZZI, 2009) (2010/11 harvest) and cultivated in the city of Ponta Grossa, PR, were used to prepare the tempeh with lyophilized inoculum of the fungus Rhizopus microsporus variety oligosporus (Type B, purified by TopCultures).

Tempeh was prepared according to the traditional method (BAVIA et al., 2012). After initial cleaning to remove foreign particles, dry and whole beans were mechanically peeled (brand MaqSoy). This process separates the cotyledons, which are used for tempeh production, in portions of $100 \mathrm{~g}$ for each sample. Cotyledons were treated in boiling water for 10 minutes. They were then drained, placed in plastic containers, immersed in water at room temperature in a ratio of 1:4 (grain/water), and maintained at room temperature for 17 hours. A second thermal treatment with boiling water for 30 minutes was carried out, and the boiled cotyledons were drained, cooled, weighed, and inoculated with spores of Rhizopus oligosporus in a ratio of 1000:1 (soybean/spores). The inoculated cotyledons were packed in polypropylene bags $(20 \times 15 \mathrm{~cm})$ that were that were perforated every square inch and thermally sealed. The samples were incubated in a growth chamber (Eletrolab, model EL222) with humidity, temperature, and photoperiod control for 24 hours. Following traditional parameters, the temperature was set to $32{ }^{\circ} \mathrm{C}$ and humidity between $50 \%$ and $60 \%$ to ensure water retention during the process. After incubation, the fresh tempeh samples were cut in half. Half of each sample was frozen (Liobrás L101, Brazil) for lyophilization, and the other half was subjected to roasting for about 2 hours at $180^{\circ} \mathrm{C}$ in an oven with forced air circulation (Fanem, model 310). Both samples were ground using a Tecnal mill, model TE631/2 to obtain the respective flours.

\subsection{Formulation of coconut cookies with mixed flour}

Three types of product were prepared using the same ingredients, except for the flour (Table 1). The control sample (CC) was formulated using cassava starch, soybean flour, refined sugar, grated coconut, margarine, and eggs (MANDARINO; BENASSI; CARRÃO-PANIZZI, 2003). Cookie A was prepared a mixture of soy flour and lyophilized tempeh flour (50\%-50\%)
Table 1. Formulations of cookies with tempeh flour $\left(\mathrm{g} .100 \mathrm{~g}^{-1}\right)$

\begin{tabular}{cccc}
\hline Ingredients & Control & Cookie A & Cookie B \\
\hline Cassava starch & 33.3 & 33.3 & 33.3 \\
Soybean flour & 14.4 & 7.2 & 7.2 \\
Refined sugar & 14.4 & 14.4 & 14.4 \\
Grated coconut & 11.5 & 11.5 & 11.5 \\
Margarine & 11.8 & 11.8 & 11.8 \\
Eggs & 14.6 & 14.6 & 14.6 \\
Lyophilized tempeh flour & 0 & 7.2 & 0 \\
Roasted tempeh flour & 0 & 0 & 7.2 \\
\hline${ }^{*}$ Each formulation yields approximately 65 cookies with average weight of 10 grams.
\end{tabular}

and cookie B with a mixture of soy flour and roasted tempeh flour (same amount).

For each formulation, the eggs were mixed with sugar and margarine until forming a homogeneous cream. Subsequently, soy flour (or flour mixture, depending on the formulation), cassava starch, and grated coconut were added to the cream (with the mixer turned off) and slowly mixed by hand to obtain a smooth and uniform dough that will not stick to the hands. The dough was spread using a rolling pin on a flat pre-cleaned surface and then cut with a circular stainless steel pastry cutter ( $4 \mathrm{~cm}$ diameter). The raw cookies were placed on baking trays greased with margarine and sprinkled with flour. The cookies were baked in a pre-heated gas oven for 10 minutes at low temperature (about $150{ }^{\circ} \mathrm{C}$ ). After baking, the cookies were removed from the oven and cooled to room temperature. They were then packed in plastic bags, identified, and vacuum sealed for later sensory analyses. Eight cookies were randomly chosen from each formulation and were ground to determine proximate composition, fatty acid profile, aglycones, and total isoflavones content.

\subsection{Proximate composition}

The fresh cookies were ground in a using a Tecnal mill (model TE631/2) to fine powder with particle size of 40 mesh. The proximate composition was determined according to official methods (ASSOCIATION..., 1995; ZENEBON; PASCUET; TIGLEA, 2008). Moisture was determined at $105^{\circ} \mathrm{C}$ and ashes at $550{ }^{\circ} \mathrm{C}$; the lipids were determined by Soxhlet method, and proteins by the Kjeldahl method with the conversion factor of 6.25. The total carbohydrates were calculated by difference.

\subsection{Isoflavone profile}

The quantification of total isoflavones and aglycones was performed by high performance liquid chromatography (HPLC). The samples were extracted with $70 \%$ ethanol solution in ultrapure water and added with glacial acetic acid $(0.1 \%)$ (BERHOW, 2002; CARRÃO-PANIZZI; FAVONI; KIKUCHI, 2002). After extraction, the samples were centrifuged for 15 minutes (Eppendorf $5417 \mathrm{R}$ ) at $5{ }^{\circ} \mathrm{C}$ and $21.000 \mathrm{G}$. The supernatant obtained was filtered through $0.45 \mu \mathrm{m}$ pore microfilters, and $20 \mu \mathrm{L}$ of the filtered extract were injected for separation and quantification of isoflavones in a Waters liquid 
chromatograph equipped with photodiode array detector Waters PDA 996.

Elution and separation of isoflavones were performed using an ODS C18YMC-Pack ODS-AM reverse phase column with particles of $5 \mu \mathrm{m}, 4.6 \mathrm{~mm}$ diameter, and $250 \mathrm{~mm}$ length, using a linear gradient system. The initial gradient conditions were: $20 \%$ eluent A (methanol acidified with $0.025 \%$ trifluoroacetic acid) and $80 \%$ eluent $B$ (ultrapure water acidified with $0.025 \%$ trifluoroacetic acid) with constant inversion until achieving $90 \%$ of eluent A and $10 \%$ of eluent B after 35 minutes. Column cleaning was performed with $100 \%$ of eluent A for 5 minutes, followed by inversion to initial gradient conditions and a 20 minutes column re-equilibration before the next injection. The total analysis time was 60 minutes per injection, and the solvent flow was maintained at $1 \mathrm{~mL} \cdot \mathrm{min}^{-1}$. HPLC grade reagents were used in all steps. For isoflavone quantification, external standard calibration curves were used (Sigma brand standards and known concentrations).

\subsection{Fatty acid profile}

The fatty acid profile was determined by gas chromatography (BANNON et al., 1982; CHRISTIE, 1989). For each sample, 0.200 grams of finely ground material was weighed and transferred to $50 \mathrm{~mL}$ Falcon tubes with screw cap. The methylation for subsequent injection was performed by adding $5 \mathrm{~mL}$ of $1 \%$ sodium methoxide in methanol, followed by stirring every 15 minutes for 60 minutes. Afterwards, $1 \mathrm{~mL}$ of $10 \%$ acetic acid and $10 \mathrm{~mL}$ of GC grade $\mathrm{n}$-heptane were added to each sample for acidification, and it was shaken for 10 seconds. The samples were let sit for 10 minutes for phase separation for phase separation, and $2 \mathrm{~mL}$ of the upper phase, containing the fatty acid methyl esters already solubilized in heptane, were pipetted into glass vials. Two $\mu \mathrm{L}$ of methylated sample was injected into a Trace Ultra Gas GC chromatograph equipped with a Supelco SP-2340 capillary silica column (30 meters length, $0.32 \mathrm{~mm}$ internal diameter, and $0.2 \mu \mathrm{m}$ film thickness). The injection was performed in split mode $(20: 1)$ at $250^{\circ} \mathrm{C}$, and separation was carried out with initial temperature of $170{ }^{\circ} \mathrm{C}$ and heating ramp up to $220^{\circ} \mathrm{C}$ in 15 minutes. Detection was performed by flame ionization at $300^{\circ} \mathrm{C}$. The gas flow was set at $30 \mathrm{~mL} \cdot \mathrm{min}^{-1}$ for nitrogen, $35 \mathrm{~mL} . \mathrm{min}^{-1}$ for hydrogen, and $350 \mathrm{~mL} \cdot \mathrm{min}^{-1}$ for synthetic air. The total running time for each sample was 18 minutes.

\subsection{Sensory analysis}

Acceptability and purchase intention tests were conducted for the three formulated cookies. The panel was composed of 150 untrained male and female subjects, aged between 17 and 60 years, with average level of education. Each taster was offered only one of the three formulations. The acceptability test evaluated four attributes (aroma, flavor, texture, and overall acceptance), and a 10-point hybrid hedonic scale anchored in its extremes with "dislike extremely" and "like extremely", respectively, and "not liked nor disliked" at the center was used. The participants were instructed to indicate how much they liked the sample for each attribute evaluated. A 5-point purchasing intention scale was used ("certainly buy"; "probably buy", "maybe buy, maybe not", "probably not", "certainly not”). Sensory analysis was approved by the Bioethics and Ethics Committee of the Irmandade Santa Casa de Londrina - BIOISCAL (Project \# 355/10 = CAAE: 0015.0.083.000-10).

\subsection{Data treatment}

The data of the chemical determinations and the sensory tests were analyzed using the technique of variance analysis, and means were compared by Tukey test at $5 \%$ probability using the Assistat software.

\section{Results and discussion}

The proximate composition data of the cookies (Table 2) shows that partial substitution of the soy flour for roasted and lyophilized tempeh flour significantly changes proteins, lipid carbohydrates, and ashes content. As for the protein level, formulation A (lyophilized tempeh flour) showed lower and different values compared to those of the other flours; similar behavior was found for formulation B (roasted tempeh flour) in terms of fat content.

In contrast, the lipid levels of the control and $\mathrm{B}$ formulations were similar, but formulation A showed reduced levels when compared to those of the control formulation. The carbohydrate content increased when the tempeh flours were used, showing a higher concentration of sugars in the tempeh flours produced.

The results for aglycones (Table 3 ) showed a significant increase when the tempeh flours were included, evidencing a nutritional and functional improvement due to greater aglycone concentration (ROSA et al., 2009). These results confirm the conversion of isoflavone glucosides into aglycone during soybean fermentation with Rhizopus oligosporus. The predominance of aglycone forms, which account for $75 \%$ of total isoflavones content after incubation in tempeh

Table 2. Proximate composition of formulated cookies (g.100 g $\left.\mathrm{g}^{-1}\right)$.

\begin{tabular}{cccc}
\hline & Control & Cookie A & Cookie B \\
\hline Lipids & $19.37 \pm 0.54^{\mathrm{A}}$ & $17.16 \pm 0.35^{\mathrm{B}}$ & $19.11 \pm 0.57^{\mathrm{A}}$ \\
Proteins & $6.22 \pm 0.13^{\mathrm{A}}$ & $6.31 \pm 0.21^{\mathrm{A}}$ & $5.19 \pm 0.14^{\mathrm{B}}$ \\
Ashes & $1.06 \pm 0.13^{\mathrm{A}}$ & $0.70 \pm 0.15^{\mathrm{B}}$ & $0.67 \pm 0.08^{\mathrm{B}}$ \\
Moisture & $4.49 \pm 0.15^{\mathrm{A}}$ & $4.60 \pm 0.12^{\mathrm{A}}$ & $4.61 \pm 0.13^{\mathrm{A}}$ \\
Carbohydrates $^{1}$ & $68.86 \pm 0.63^{\mathrm{B}}$ & $71.23 \pm 0.44^{\mathrm{A}}$ & $70.42 \pm 0.59^{\mathrm{A}}$ \\
\hline
\end{tabular}

Means followed by the same capital letters in the same line, for each parameter, are not significantly different by Tukey test $(\mathrm{p}>0.05)$. Mean of six repetitions. ${ }^{1}$ Calculated by difference. Cookie $\mathrm{A}=$ mixed flour with soybean and lyophilized tempeh; Cookie $\mathrm{B}=$ mixed flour with soybean and roasted tempeh.

Table 3. Levels of total isoflavones and aglycone in the formulated cookies (mg.100 g $\mathrm{g}^{-1}$ ).

\begin{tabular}{cccc}
\hline & Control & Cookie A & Cookie B \\
\hline Aglycones & $6.30 \pm 0.30^{\mathrm{C}}$ & $24.78 \pm 1.12^{\mathrm{A}}$ & $20.69 \pm 0.38^{\mathrm{B}}$ \\
Total Isoflavones & $38.09 \pm 0.71^{\mathrm{A}}$ & $38.76 \pm 1.42^{\mathrm{A}}$ & $31.29 \pm 0.68^{\mathrm{B}}$ \\
\hline
\end{tabular}

Means followed by the same capital letters in the same line, within each parameter, are not significantly different by Tukey test ( $p>0.05$ ). Mean of six repetitions. Deffated basis. Cookie $\mathrm{A}=$ mixed flour with soybean and lyophilized tempeh; Cookie $\mathrm{B}=$ mixed flour with soybean and roasted tempeh. 
(NAKAJIMA et al., 2005), enhances the benefit of tempeh flour as an alternative to soy flour. When compared to the A and $\mathrm{B}$ cookies (prepared with roasted tempeh flour), the latter showed lower values for both aglycone and total isoflavones content. This reduction can be explained by the high temperatures achieved during the processes $\left(180^{\circ} \mathrm{C}\right.$ for tempeh drying, $150{ }^{\circ} \mathrm{C}$ for cookie baking) which affects isoflavone conversion (SUQIN et al., 2009).

As for the fatty acids (Table 4), there was a difference between the control formulation and the cookies made with roasted tempeh flour (B) only in terms of the linolenic acid content, which was low in both formulations. The similarity between the control cookie and cookie B proves that short fermentation, such as that of tempeh production, does not significantly change the fatty acid profile of soybean (BISPING et al., 1993), preserving the oleic, linoleic (omega-6),

Table 4. Levels of fatty acids in formulated cookies ( $\left.\mathrm{g} \cdot 100 \mathrm{~g}^{-1}\right)$.

\begin{tabular}{cccc}
\hline & Control & Cookie A & Cookie B \\
\hline Palmitic & $2.41 \pm 0.11^{\mathrm{A}}$ & $2.15 \pm 0.10^{\mathrm{B}}$ & $2.34 \pm 0.09^{\mathrm{A}}$ \\
Stearic & $1.47 \pm 0.07^{\mathrm{A}}$ & $1.33 \pm 0.05^{\mathrm{B}}$ & $1.46 \pm 0.04^{\mathrm{A}}$ \\
Oleic & $3.93 \pm 0.20^{\mathrm{A}}$ & $3.45 \pm 0.14^{\mathrm{B}}$ & $3.87 \pm 0.11^{\mathrm{A}}$ \\
Linoleic & $7.46 \pm 0.35^{\mathrm{A}}$ & $6.35 \pm 0.26^{\mathrm{B}}$ & $7.29 \pm 0.21^{\mathrm{A}}$ \\
Linolenic & $0.87 \pm 0.04^{\mathrm{A}}$ & $0.72 \pm 0.03^{\mathrm{C}}$ & $0.82 \pm 0.02^{\mathrm{B}}$ \\
Arachidic & $0.07 \pm 0.003^{\mathrm{A}}$ & $0.06 \pm 0.003^{\mathrm{B}}$ & $0.07 \pm 0.004^{\mathrm{A}}$ \\
Total & $16.22 \pm 0.75^{\mathrm{A}}$ & $14.06 \pm 0.57^{\mathrm{B}}$ & $15.85 \pm 0.47^{\mathrm{A}}$ \\
\hline
\end{tabular}

Means followed by the same capital letters in the same line, within each parameter are not significantly different by Tukey test $(\mathrm{p}>0,05)$. Mean of six repetitions. Cookie $\mathrm{A}=$ mixed flour with soybean and lyophilized tempeh; Cookie $\mathrm{B}=$ mixed flour with soybean and roasted tempeh.

Table 5. Acceptability test results of formulated cookies.

\begin{tabular}{cccc}
\hline & Control & Cookie A & Cookie B \\
\hline Aroma & $8.17 \pm 1.55^{\mathrm{A}}$ & $8.16 \pm 1.62^{\mathrm{A}}$ & $7.03 \pm 2.10^{\mathrm{B}}$ \\
Flavor & $8.50 \pm 1.44^{\mathrm{A}}$ & $8.63 \pm 1.24^{\mathrm{A}}$ & $7.59 \pm 2.08^{\mathrm{B}}$ \\
Texture & $7.73 \pm 2.04^{\mathrm{A}}$ & $8.16 \pm 1.62^{\mathrm{A}}$ & $7.83 \pm 2.07^{\mathrm{A}}$ \\
Overall acceptance & $8.25 \pm 1.35^{\mathrm{AB}}$ & $8.45 \pm 1.22^{\mathrm{A}}$ & $7.71 \pm 1.89^{\mathrm{B}}$ \\
\hline
\end{tabular}

Means followed by the same capital letters in the same line, within each parameter are not significantly different by Tukey test $(\mathrm{p}>0,05)$. Mean of 50 repetitions. Cookie $\mathrm{A}=$ mixed flour with soybean and lyophilized tempeh; Cookie $\mathrm{B}=$ mixed flour with soybean and roasted tempeh.

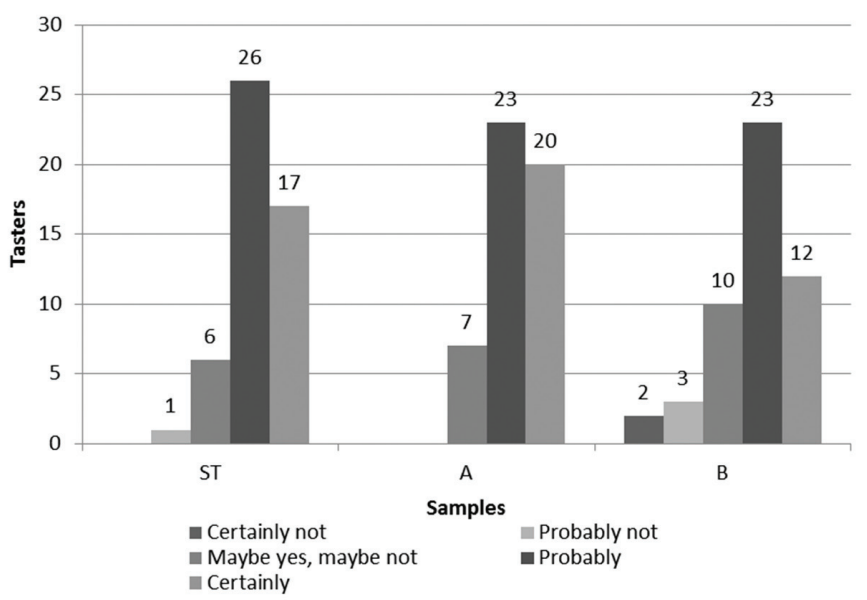

Figure 1. Graphical distribution for purchase intention of formulated cookies. and linolenic (omega-3) acids, which are important in the prevention of coronary heart diseases (CONNOR, 2000). When combined with the total lipids content, the sum of fatty acids corresponds to $82 \%-83 \%$ of the lipids found, which is a standout factor for tempeh flour use.

In the sensory evaluations, the average scores of the acceptance testing (Table 5) showed similarity between the control cookie and the samples made with mixed flour of soybean and lyophilized tempeh (A), with slightly higher scores for the latter. This result is indicative of a consumer preference for lyophilized tempeh flour, especially in terms of texture. However, based on the scale used (0 to 10), sample B also obtained satisfactory scores, and the acceptability index of the samples A and B (above 70\%) indicates that there was no sensory loss when they are compared to the control. The lowest averages (cookie B) may have been caused by a problem during the roasting process, which reflected in the aroma and flavor of the final product.

As for the purchase intention results (Figure 1), sample A also obtained results similar to those of the control cookie, considering the two highest (positive) scores and the change in intention represented by higher scores. This test evidenced lower preference for cookie B, However, the results were similar to those of the control sample and were considered satisfactory for this type of evaluation, with positive purchase intention for 35 of the 50 tasters $(70 \%)$.

\section{Conclusion}

Fermentation with Rhizopus oligosporus did not affect the levels and profile of fatty acids in the roasted tempeh flour, maintaining the concentrations of linoleic and linolenic acids originally present in the soybean flour almost unchanged.

The significant increase in aglycone levels in the cookies made with mixed flour emphasizes the functional importance of tempeh flour, especially for easily accepted products by the consumer, such as cookies and biscuits.

The cookies prepared with partial replacement of soy flour with tempeh flour showed satisfactory results for acceptance and purchase intention, with acceptability indexes higher than $70 \%$, indicating their use as functional enhancers without loss of sensory quality in the final product.

\section{Acknowledgments}

The authors acknowledge the financial support provided by CAPES.

\section{References}

ASSOCIATION OF OFFICIAL ANALYTICAL CHEMISTS - AOAC. Official Methods of Analysis of AOAC International. 16 ed. Arlington: AOAC International; 1995. 1658 p.

BANNON, C. D. et al. Analysis of fatty acid methyl esters with high accuracy and reliability: III. Literature review of and investigations into the development of rapid procedures for the methoxidecatalysed methanolysis of fats and oils. Journal of Chromatography A, v. 247, n. 1, p. 71-89, 1982. 
BAVIA, A. C. F. et al. Chemical composition of tempeh from soybean cultivars specially developed for human consumption. Ciência e Tecnologia de Alimentos, v. 32, n. 3, p. 613-20, 2012. http://dx.doi. org/10.1590/S0101-20612012005000085

BERHOW, M. A. Modern analytical techniques for flavonoid determination. In: BUSLIG, B. S.; MANTHEY, J. A. (Eds). Flavonoids in the living cell. New York: Klusher Academic, 2002. 209 p. http://dx.doi.org/10.1016/S0021-9673(00)84857-8

BISPING, B. et al. Tempeh fermentation: some aspects of formation of gama-linolenic acid, proteases and vitamins. Biotechnology Advances, v. 11, p. 481-93, 1993.

CARRÃO-PANIZZI, M. C. Breeding specialty soybean cultivars for processing and value-added utilization at Embrapa in Brazil. In: WORLD SOYBEAN RESEARCH CONFERENCE, 8, 2009. Beijing. Proceedings... Beijing: Chinese Academy of Agricultural Sciences; Institute of Crop Science, 2009.

CARRÃO-PANIZZI, M. C.; FAVONI, S. P. G.; KIKUCHI, A. Extraction time for isoflavone determination. Brazilian Archives of Biology and Technology, v. 45, n. 4, p. 515-8, 2002.

CHRISTIE, W. W. Gas chromatography and lipids: A practical guide. Scotland: Oily, 1989. 307 p. PMid:16473782. http://dx.doi. org/10.1263/jbb.100.685

COMPANHIA NACIONAL DE ABASTECIMENTO - CONAB. Acompanhamento da Safra Brasileira: Grãos. Brasília: CONAB, 2013. Disponível em: <http://www.conab.gov.br/OlalaCMS/uploads/ arquivos/13_07_09_09_04_53_boletim_graos_junho_2013.pdf $>$. Acesso em: 10 jul. 2013.

CONNOR, W. E. Importance of n-3 fatty acid in health and disease. American Journal of Clinical Nurtition, v. 71, p. 171-5, 2000.

DANTAS, M. I. S. et al. Farinhas de soja sem lipoxigenase agregam valor sensorial em bolos. Revista Ceres, v. 57, n. 2, p. 141-4, 2010. http://dx.doi.org/10.1590/S0034-737X2010000200001

FERREIRA, M. P. et al. Changes in the isoflavone profile and in the chemical composition of tempeh during processing and refrigeration. Pesquisa Agropecuária Brasileira, v. 46, n. 11, p. 1555-61, 2011. http://dx.doi.org/10.1590/S0100-204X2011001100018

FERREIRA, V. L. P. Análise sensorial: testes discriminativos e afetivos. In: FERREIRA, V. L. P. (Org.). Manual: série qualidade. Campinas: SBCTA, 2000. 127 p.

FRANKS, F. Freeze-drying of bioproducts: putting principles into practice. European Journal of Pharmaceutics and Biopharmaceutics, v. 45, p. 221-9, 1998. http://dx.doi.org/10.1016/ S0939-6411(98)00004-6

GUILHERME, F. F. P.; JOKL, L. Emprego de fubá de melhor qualidade protéica em farinhas mistas para produção de biscoito. Ciência e Tecnologia de Alimentos, v. 25, n. 1, p. 63-71, 2005. http://dx.doi. org/10.1590/S0101-20612005000100011

MANDARINO, J. M. G.; BENASSI, V. T.; CARRÃO-PANIZZI, M. C. Documentos 206: manual de receitas com soja. Londrina: Embrapa Soja, 2003. 60 p.
McCUE, P.; SHETTY, K. Health benefits of soy isoflavonoids and strategies for enhancement: A review. Critical Review in Food Science and Nutrition, v. 44, p. 361-7, 2004. PMid:15540649. http:// dx.doi.org/10.1080/10408690490509591

MINIM, V. P. R. Análise sensorial: estudos com consumidores. Viçosa: UFV, 2006. 225 p.

$\mathrm{MO}$, H. et al. Effect of soybean processing on content and bioaccessibility of folate, vitamin B12 and isoflavones in tofu and tempe. Food Chemistry, v. 141, p. 2418-25, 2013. PMid:23870976. http://dx.doi. org/10.1016/j.foodchem.2013.05.017

NAKAJIMA, N. et al. Analysis of isoflavone content in tempeh, a fermented soybean, and preparation of a new isoflavone-enriched tempeh. Journal of Bioscience and Bioengeneering, v. 100, n. 6, p. 685-7, 2005. http://dx.doi.org/10.1016/0734-9750(93)90016-G

NOWAK, J.; SZEBIOTKO, K. Some biochemical changes during soybean and pea tempeh fermentation. Food Microbiology, v. 9, p. 37-43, 1992. http://dx.doi.org/10.1016/0740-0020(92)80060-H

ROSA, A. M. et al. Alimentos fermentados à base de soja (Glycinemax (Merrill) L.): importância econômica, impacto na saúde e efeitos associados às isoflavonas e seus açúcares. Brazilian Journal of Biosciences, v. 7, n. 4, p. 454-62, 2009. http://dx.doi.org/10.1016/j. jff.2008.09.013

SILVA, L. H.; CELEGHINI, R. M. S.; CHANG, Y. K. Effect of the fermentation of whole soybean flour on the conversion isoflavones from glycosides to aglycones. Food Chemistry, v. 128, p. 640-4, 2011. http://dx.doi.org/10.1016/j.foodchem.2011.03.079

SILVA, L. H. et al. Caracterização físico-química e tecnológica da farinha de soja integral fermentada com Aspergillus oryzae. Brazilian Journal of Food Technology, v. 15, n. 4, p. 300-6, 2012. http://dx.doi.org/10.1590/S1981-67232012005000025

SUQIN, S. et al. Tracking isoflavones: From soybean to soy flour, soy proteinisolates to functional soy bread. Journal of Functional Foods, v. 1, p. 119-27, 2009. http://dx.doi.org/10.1590/S141552732006000600011

TATTINI, V.; PARRA, D. F.; PITOMBO, R. N. M. Influência da taxa de congelamento no comportamento físico-químico e estrutural durante a liofilização da albumina bovina. Brazilian Journal of Pharmaceutical Sciences, v. 42, n. 1, p. 127-36, 2006.

TERESA, S. P. et al. Absorption of isoflavones in humans: effects of food matrix and processing. Journal of Nutritional Biochemistry, v. 17, p. 257-264, 2006. PMid:16109484. http://dx.doi.org/10.1016/j. jnutbio.2005.04.008

VillanueVA, N. D. M.; PETEnATE, A. J.; Silva, M. A. A. P. Performance of the hybrid hedonic scale as compared to the traditional hedonic, self-adjusting and ranking scales. Food Quality and Preference, v. 16, p. 691-703, 2005. http://dx.doi.org/10.1016/j. foodqual.2005.03.013

ZENEBON, O.; PASCUET, N. S.; TIGLEA, P. Métodos físico-químicos para análise de alimentos. 4 ed. São Paulo: Instituto Adolfo Lutz; 2008. 1020 p. 